IZA DP No. 5498

Savings, Asset Holdings, and Temporary Migration

Christian Dustmann

Josep Mestres

February 2011

Forschungsinstitut zur Zukunft der Arbeit Institute for the Study of Labor 


\title{
Savings, Asset Holdings, and Temporary Migration
}

\author{
Christian Dustmann \\ University College London, \\ CReAM and IZA \\ Josep Mestres \\ University College London \\ and CReAM
}

\section{Discussion Paper No. 5498 \\ February 2011}

\author{
IZA \\ P.O. Box 7240 \\ 53072 Bonn \\ Germany \\ Phone: +49-228-3894-0 \\ Fax: +49-228-3894-180 \\ E-mail: iza@iza.org
}

\begin{abstract}
Any opinions expressed here are those of the author(s) and not those of IZA. Research published in this series may include views on policy, but the institute itself takes no institutional policy positions.

The Institute for the Study of Labor (IZA) in Bonn is a local and virtual international research center and a place of communication between science, politics and business. IZA is an independent nonprofit organization supported by Deutsche Post Foundation. The center is associated with the University of Bonn and offers a stimulating research environment through its international network, workshops and conferences, data service, project support, research visits and doctoral program. IZA engages in (i) original and internationally competitive research in all fields of labor economics, (ii) development of policy concepts, and (iii) dissemination of research results and concepts to the interested public.
\end{abstract}

IZA Discussion Papers often represent preliminary work and are circulated to encourage discussion. Citation of such a paper should account for its provisional character. A revised version may be available directly from the author. 
IZA Discussion Paper No. 5498

February 2011

\section{ABSTRACT}

\section{Savings, Asset Holdings, and Temporary Migration*}

This paper analyzes savings and asset holdings of immigrants in relation to their return plans. We argue that savings and asset accumulation may be affected by return plans of immigrants. Further, the way savings and assets are held in the home- and host country may also be related to future return plans. Thus, comparing savings and assets between immigrants and natives may lead to serious underestimation when neglecting the home country component. We show that immigrants with temporary return plans place a higher proportion of their savings in the home country. In addition, both the magnitude and the share of assets and housing value accumulated in the home country are larger for immigrants who consider their migration as temporary, and lower the value of assets and property held in the host country. Finally, and conditional on observable characteristics, we find no evidence that immigrants with temporary migration plans save more than immigrants with permanent migration plans.

JEL Classification: F22, D31, R21

Keywords: international migration, wealth accumulation, housing demand

Corresponding author:

Christian Dustmann

Department of Economics

University College London

Gower Street

London, WC1E 6BT

United Kingdom

E-mail: c.dustmann@ucl.ac.uk

\footnotetext{
* This research has been financially supported by the Austrian, German, Korean, and Norwegian governments through the Multi-donor Trust Fund on Labor Markets, Job Creation, and Economic Growth administered by the World Bank's Social Protection and Labor unit.
} 


\section{INTRODUCTION}

The economic performance of immigrants is important for assessment of the welfare implications of immigration. Not surprisingly therefore, a large number of papers investigates the (relative) earnings position of immigrants over the migration cycle, for different countries, and using both cross-section and time-series data. ${ }^{1}$ An area that has received less attention, but is perhaps equally important for assessing the economic position of immigrants in the receiving country, is their asset accumulation and savings. Like earnings, assets and savings are likely to be affected by plans about a future return. Return intentions in the past may have affected past earnings as well as past expenditures, and therefore the magnitude of current asset holdings and past and current savings. $^{2}$ Furthermore, past and current return intentions may determine where assets and savings are held. For instance, when considering housing and other investments, these may be undertaken in the country of origin if migrations are intended as temporary rather than permanent. ${ }^{3}$

A number of papers analyse the wealth gap between immigrants and natives. Most of these report a persistent gap, even conditional on observable characteristics ${ }^{4}$. However, most measures of immigrant wealth do not consider immigrants' wealth in the home- and host country separately. Hence, an analysis that considers wealth accumulation without differentiating between locations may only give an incomplete picture of asset holdings and savings. In addition, most

${ }^{1}$ From the early works of Chiswick (1978) and Borjas (1985) to Dustmann (1993), Friedberg (1993), Borjas (1995), Barth et al. (2004), Bratsberg et al (2006) and Lubotsky (2007) among others.

${ }^{2}$ See Dustmann $(1995,1997)$ for a theoretical analysis of the interaction between return migration and immigrant savings.

${ }^{3}$ See Woodruff and Zenteno (2007) and Yang (2008) for evidence on the creation of enterprises of immigrants in their home countries while abroad. Dustmann and Kirchkamp (2002) and Mesnard (2004) provide evidence of immigrants undertaking entrepreneurial activities after return.

${ }^{4}$ See for example Blau and Graham (1990), Coulson (1999), Borjas (2002), Amuedo-Dorantes and Pozo (2002), Painter et al. (2003), Osili and Paulson (2004), Cobb-Clark and Hildebrand (2006), Sinning (2007, 2009) or Bauer et al. (2011). 
of these studies do not allow either for heterogeneity across immigrants due to differences in past and current return plans. ${ }^{5}$

In this paper, we provide an analysis of immigrant savings and asset holdings in relation to past and current return plans. We also consider the possibility that savings and assets are held not only in the host country, but also in the country of origin. Our analysis is based on a unique data source that provides information on asset holdings, its composition and location, as well as immigrants' return plans. We describe immigrants' asset accumulation and savings, and how it relates to return intentions, as well as individual and household characteristics. The paper makes two contributions. First, it provides analysis of the relationship between return plans, on the one hand, and savings and asset holdings on the other. Second, it illustrates the importance of considering migrants' asset holdings not only in the host- but also the home country.

Our results show that the overall level of savings and asset accumulation of immigrants would be severely underestimated if the home country wealth is not taken into consideration. In addition, we show how immigrants' return plans are related to wealth accumulation. The total value of assets held does not differ significantly between immigrant households with temporary intentions and those with permanent ones. However, the distribution of these assets between host- and home country location does differ. Migrants who plan to return do allocate a higher proportion of their savings, assets and property in their home country.

The structure of the paper is as follows: in the next section we discuss conceptual considerations, in section 3 we present our data and explain the descriptive evidence, in section 4 we show our results and finally in section 5 we conclude and discuss potential implications.

\footnotetext{
${ }^{5}$ An exception is Bauer and Sinning (2011), who found that savings behaviour of migrants is related to their return plans. The analysis considers different measures of migrant savings, assuming either that no remittances are saved or that all remittances are saved, without differentiating between remittance purposes. It does not investigate immigrant home-ownership or asset holdings.
} 


\section{CONCEPTUAL CONSIDERATIONS AND ESTIMA- TION}

\subsection{A Simple Model}

We start with a simple model that focuses on the way temporary vs permanent migrations relate to savings behavior. A more detailed analysis of the interplay between savings and return (both exogenous and optimally chosen) can be found in DUSTMANN [1995].

As in GALOR and STARK [1990], suppose the lifetime of the immigrant can be divided into 2 sub-periods: period 1 is the time to be spent in the host country, and period 2 is the time to be spent in the home country after a possible return. Return in period 2 takes place with probability $p$. In the case that $p=0$, the migration is permanent. Consider the following inter-temporal utility function:

$$
U=u^{1}\left(c^{1}\right)+p \beta \tilde{u}^{2}\left(c^{E 2}\right)+(1-p) u^{2}\left(c^{I 2}\right) .
$$

In equation (1), $u^{1}$ is the sub-utility in period 1 in the host country and $\tilde{u}^{2}$ and $u^{2}$ are the sub-utilities in period 2 in the home and in the host country respectively, which we assume as being strictly concave in consumption. Further, $c^{1}, c^{I 2}$ and $c^{E 2}$ are first and second period consumption in immigration (index $I$ ) and emigration (index $E$ ) countries respectively. The parameter $p \in[0,1]$ is the probability the migrant attaches to a possible return to the home country in the second period.

Consumption in the second period in the case of a return may induce more utility than consumption in the host country, due to complementarities through climate, friends, etc. This is captured by the parameter $\beta$. If $\beta>1$, the migrant has a higher level of utility and a higher marginal utility if he/she consumes in the home country.

The budget constraint for the first period is given by $w^{1}=c^{1}+s$. The budget constraint for the second period is $w^{I 2}+s=c^{I 2}$ in the case of a permanent migration and $w^{E 2}+r s=c^{E 2}$ in the case of a return. Earnings in period 1 are denoted by $w^{1}$, and in period 2 by $w^{E 2}$ and $w^{I 2}$ in home and host countries respectively. The purchasing power of the host country currency in 
the home country is given by $r$. If $r>1$, the purchasing power of the host country currency is higher in the migrant's home country. ${ }^{6}$

The choice variable in period 1 is savings $s$. Given the budget constraint, it fixes consumption in the first period $\left(c^{1}\right)$ and in the second period $\left(c^{E 2}, c^{I 2}\right)$. The first order condition is given by:

$$
\frac{d}{d s}: u_{1}^{1}=p \beta \tilde{u}_{1}^{2} r+(1-p) u_{1}^{2}
$$

where the subscript ${ }_{1}$ denotes the first derivative.

Equation (2) determines the optimal level of savings. Savings will be set such that the marginal cost in terms of forgone utility in period 1 is equalized to the expected marginal return in period 2. If $p=0$ (the migration is permanent), savings will equalize the marginal utility of consumption in the two periods in the host country. If $p \in(0,1)$, a change in $p$ leads to a change in savings according to the following relationship:

$$
\frac{d s}{d p}=\frac{-\left[r \beta \tilde{u}_{1}^{2}\left(w^{E}+r s\right)-u_{1}^{2}\left(w^{I}+s\right)\right]}{u_{11}^{1}+p \beta r^{2} \tilde{u}_{11}^{2}+(1-p) u_{11}^{2}} .
$$

The expression in the denominator is always negative. Assume first that $\beta=1$ and $r=1$ : Preferences for consumption are the same in the two countries, as is the purchasing power of the host country currency. In that case, savings will be increasing in $p$ as long as $w^{E}<w^{I}$, due to strict concavity of the utility function. The intuition is that an increase in savings increases the marginal utility of consumption by more in the home country, due to lower wages; thus, an increase in the return probability $p$ leads to higher savings. Now suppose that $\beta>1$ : Individuals prefer to consume at home rather than abroad. This will reinforce the effect of an increase in the return probability on savings. Finally, suppose that the purchasing power of the host country currency is higher at home so that $r>1$. In this case, the overall effect on savings is ambiguous, as it is now unclear whether an increase in savings increases the marginal utility of consumption more in the home- or the host country. Sufficient for the effect of an increase in $p$ on savings to be positive is that the wage differential between home- and host country is larger than the

\footnotetext{
${ }^{6}$ For simplicity we have assumed that interest rates are equal in the two countries; if interest rates were different between home and host country then this would be an additional source of differential asset accumulation.
} 
gain obtained on savings through the purchasing power differential $w^{I}-w^{E}>(r-1) s$. Thus, according to this simple model, savings may be positively or (if purchasing power differentials are important) negatively affected by an increase in the return probability, or the two effects may compensate each other.

Our simple model has nothing to say however about where savings are held. It may well be that immigrants who assign a high probability to a return are more likely to transfer some of their savings to the home country. If that is the case, an empirical analysis of immigrants' savings may lead to an underestimate when only considering savings in the host economy.

Now consider asset holdings, like housing assets or long-term investments. If these are proportional to the level of past savings, then our simple life-cycle model should suggest that in general, the relationship to the temporariness of a migration is ambiguous. The model does not explain where these assets are held. However, it is not unlikely that immigrants who assign a high probability to a later return have a preference for accumulation in the home country. This is particularly the case for assets that have the character of durable consumption goods, and that can not be moved from one place to another, like housing assets.

\subsection{Empirical Implementation}

In the empirical analysis we regress the various outcome variables on a vector of individual specific characteristics, country of origin dummies, and a measure for the probability to return. The generic regression has the form

$$
Y_{i}=\alpha_{1}+X_{i}^{\prime} \alpha_{2}+\gamma T_{i}+u_{i}
$$

where $Y_{i}$ is the respective outcome, $X_{i}$ is a vector of background characteristics, $u_{i}$ is an error term, and $T_{i}$ is a measure for the temporariness of a migration. As we explain below, in our data we observe for each year an indicator question whether or not the individual would like to return home at some point in the future. These intentions may change over time, and accordingly affect the savings- and asset holding decision. In our analysis, we will use the average intention to return, computed from information over the last five years, as a measure of temporariness when 
analyzing asset holdings, and the current intention to return when analyzing current savings.

We would like to emphasize that we do not interpret our estimates as causal. While in our simple model, the return probability is exogenously given, immigrants may well choose whether they wish to return, and this choice may not be exogenous to savings- or asset accumulation decisions. Further, our measure for the temporariness of a migration may well be measured with error, which would bias the coefficient estimate towards zero. We believe however that the associations between the temporariness of a migration on the one hand, and savings- and asset accumulation behavior, as well as the choice of where these are to be held, conditional on background characteristics, are interesting and important. ${ }^{7}$ The overall comparison in savings and asset accumulation between immigrants and natives is of course not affected by possible endogeneity of return migrations.

\section{BACKGROUND AND DATA}

\subsection{Background}

The West-German economy experienced a strong upward swing after 1955, accompanied by a sharp fall in the unemployment rate. Between 1955 and 1960, the unemployment rate fell from 5.6 $\%$ to $1.3 \%$ (BUNDESAGENTUR FUER ARBEIT [2009]). At the same time, the percentage of foreign born workers from Southern European countries and Turkey employed in West Germany increased from 0.6 percent in 1957 to 5.3 percent in 1965, to 11.2 percent in 1973 (see BLITZ [1977]). Immigration was regulated by bilateral recruitment agreements. Such agreements were set up with Italy, Spain, Greece, Turkey, Portugal and Yugoslavia in the 1950's and 1960's. After 1973, recruitment of foreign labour stopped. Nevertheless, immigration from these countries

\footnotetext{
${ }^{7}$ In Dustmann and Mestres (2010) where we analyze remittances and their relationship to temporary migration decisions, we address these problems by combining a fixed effects estimator with an IV strategy. In that paper, we have access to repeated information for remittances for a large number of time periods. We find that the IV-fixed effects estimates are close to the original OLS estimates, due to the downward bias through measurement error being of similar size than the upward bias induced through unobservable heterogeneity. Assets and savings - which we analyze in this paper - are only observed once or twice over the course of the panel.
} 
continued, due to family reunification (see DUSTMANN [1996] for more details). The immigrant population we study in this paper stems from that migration movement. Labor migration over this period was initially considered as temporary by both the immigration countries and the emigration countries. Still, although return migration has been quite considerable (see BOHNING [1987]), a large fraction of foreign born workers settled permanently ${ }^{8}$.

\subsection{Data and Sample}

The data set we use is the German Socio-Economic Panel (GSOEP). The GSOEP is a householdbased panel survey, similar to the US Panel Study of Income Dynamics (PSID) or the British Household Panel Study (BHPS). Initiated in 1984, the GSOEP oversamples the then-resident immigrant population in Germany, which stems from the migration movement we have described above. In the first wave, about 4500 households with a German born household head were interviewed, and about 1500 households with a foreign born household head. The data are unique in providing repeated information on a boost sample of immigrants over a long period of time. For our analysis, we use observations for the foreign born from the over-sample, as well as observations for the native born from the standard sample.

Each individual in a household and over the age of 16 is interviewed. The household head provides information about all other individuals in the household and below the interviewing age. Individuals who leave households and form their own households are included in the panel.

The GSOEP data provides information on asset holdings in both the home- and host country only for the year 1988. For that year only, there is detailed information on the type of asset holdings, their values and - importantly - whether the asset is held in the host- or source country. ${ }^{9}$ Asset holdings refer to the total amount of asset holdings of the household (including cash, savings, home ownership, etc.) net of financial obligations in each location separately. Home ownership refers to all houses, apartments or any other property of the household at market

\footnotetext{
${ }^{8}$ The stock of foreign labor in Germany in 2004 was 3.7 million people, of which around 60 per cent originated from the sending countries considered here (OECD, 2006).

${ }^{9}$ See the Appendix for a more detailed description of the data construction.
} 
prices in both home and host countries.

Savings are declared in both home- and host country locations only for the years 1992 and $1994^{10}$. Savings in the host country correspond to the net monthly savings of the household transformed to a yearly level. Savings in the home country correspond to the individual yearly amount saved in the home country and transformed to household level. We construct the total amount of household savings as the sum of the yearly amounts the household saved in both locations. We will use those two years where we observe savings in both locations (1992 and 1994) to study the allocation of savings. All monetary variables are at the household level in real amounts, where the reference year is 2002 .

A further unique feature of our data is that immigrants provide information in each wave of the panel whether they intend to remain permanently in Germany, or whether they wish to return home at some stage in the future. We use this information to differentiate between those who do and those who do not plan to return to the home country. If economic decisions are involved, it is likely that these are based on intentions of this sort, rather than on possible realizations at a later stage.

In addition, we observe individual and household characteristics in the host country, as well as information on family members who are living in the country of origin.

\section{RESULTS}

\subsection{Descriptive Evidence}

Individual Characteristics: As we mention above, we measure savings and asset accumulation on the level of the household. When we refer to characteristics of individuals within households, we typically refer to the head of household. Entries in Table 1 show that the average age of household heads in our sample is 45 years, and that migrants resided slightly less than 22

\footnotetext{
${ }^{10}$ The amount of savings in Germany is declared from 1992 onwards, while the amount saved in the home country is declared only on the years 1984-1990,1992 and 1994. See the data construction appendix for further details.
} 
years on average in Germany. Almost 90 percent of the head of households are male, and 78 percent are employed. The yearly average net household income is around 25,000 Euros (in 2002 prices). Around 93 percent of household heads are not single; however, only 7 percent have native partners. Almost 40 percent of all heads of households report that they grew up in a rural area. The last variable measures the return intention of the household head. On average, 51 percent of the household heads in our sample report that they would wish to return to their home country at some point in the future.

Savings: We study the yearly amount of savings for the years 1992 and 1994. For immigrants, savings refer to the total amount saved as well as the amounts saved in host- and home countries. As a reference, we also report savings for native born individuals. Here savings refer to the total amount saved. In the upper panel of Table 2, we describe savings for all immigrants in the first pair of columns; in next two pairs of columns we distinguish between immigrants with temporary and permanent return plans. In the following pair of columns we report the mean difference between immigrant groups and its t-statistic. The information on return plans refers to the head of household. ${ }^{11}$

About 48 percent of all immigrant households report to save in the host country. The average amount saved is 2046 Euros (not conditional on saving a positive amount), which corresponds to 7.4 percent of overall household income. Immigrants with permanent migration plans are less likely to save in the host country than than those with temporary plans, and they save a lower amount. The difference in savings in the host country corresponds to one percent of the household income. The next row shows the savings in the home country. The proportion of immigrants with temporary intentions who save is more than 4 percentage points higher than that of immigrants with permanent intentions, with the amount saved being higher as well. Both differences are significantly different statistically. Finally, the last three rows report the total amount of yearly savings. As a point of reference, we report the total amount of savings of natives in the last two columns. One in two of all immigrants households report to save, compared to 65 percent of native households. The total average amount of savings is equal

\footnotetext{
${ }^{11}$ We use all observations for which both savings or asset information and return plans are reported.
} 
to 2199 Euros (which corresponds to $8.1 \%$ of immigrants' household income, as compared to $10 \%$ for natives), which is lower than the average savings for natives both in absolute value and relative to their household incomes. ${ }^{12}$

When we distinguish between immigrants with permanent and temporary intentions, there is a clear difference between the two groups, with those with temporary intentions saving more in absolute terms, as well as in percentage of their household income.

Home Ownership and Assets: A set of questions asking about asset holdings was included in the survey in 1988. For immigrants, questions relate to property and asset holdings, both in Germany and in the home country. For natives, questions relate to total property and asset holdings. We report descriptives in the second (home ownership) and third (assets) panels of Table 2. As before, the first two columns report averages for all immigrants, while the next columns distinguish between immigrants with permanent and temporary migration plans respectively. We include the natives' average as reference in the last two columns.

Only about 8.4 percent of all immigrant households report owning housing property in Germany. Distinguishing between immigrants with temporary and permanent intentions reveals remarkable differences, however. While 14 percent of immigrants with a permanent migration intention own housing property in Germany, only 5 percent of those who wish to return do so. Likewise, the value of the housing stock is much lower for the latter category.

In the next row we report home ownership in the home country. About 44 percent of all immigrant household report to own property in the home country. Finally, the last row combines this number with the proportion of immigrants who hold property in Germany (first row). Half of the immigrants hold property in either home- or host country. This contrasts with 44 percent of native born households that hold property. The average value of immigrants' property is about 30 percent lower than that of natives; however, this may partly reflect lower property prices in the countries of origin.

In the next columns we distinguish again between immigrants with temporary and permanent

\footnotetext{
${ }^{12}$ The household savings ratio in our data is in line with aggregate data from the German Central Bank's (Bundesbank) Financial Accounts, where household savings correspond on average to $12 \%$ of household disposable income for years 1992 and 1994 (Bundesbank, 2008).
} 
return plans. One in two immigrant households with return plans reports owning housing stock in the home country, compared to just 31 percent of those with permanent intentions. In addition, the value of property in the home country is more than twice as high for those who wish to return. Overall, temporary migrants are more likely to own property. However, the total value of home ownership is similar between immigrant households who wish to return and those who do not.

The next panel reports information on asset holdings. Asset holdings refer to the total amount of assets (including cash, savings, property, etc.) net of financial obligations. For immigrants the questions draw a distinction between assets held in Germany, and assets held in the home country. The numbers suggest that if we consider only asset holdings of immigrants in the host country, the amount of asset holdings is considerably lower than those of natives. However, this difference is significantly reduced when taking into account that immigrants hold assets also in the home country. There is again a stark difference in the distribution of asset holdings between immigrants with temporary and permanent intentions. While permanent migrants hold most of their assets in the host country, temporary migrants hold assets mostly in the home country. The total amount of asset holdings is slightly higher for permanent migrants.

To summarize, these figures show that - for any comparison between immigrant and native households - it is important to consider immigrants' savings and assets in the country of origin. Further, the figures also show differences in savings, total property and asset holdings between immigrants with temporary and permanent migration plans. There are also stark differences between these two groups as to where those assets are held. Immigrants with temporary migration plans hold less property and assets than immigrants with permanent plans in the host country, but more in the home country. This points at different wealth allocation profiles between those migrants who want to return and those who do not. It also suggests that the way immigrants may possibly affect the housing market in the host- and the home country depends on their re-migration plans. 


\subsection{Conditional Results}

We now focus on the differences between immigrants with temporary and permanent migration plans. The numbers we report in Table 2 do not account for differences in household- and individual characteristics. They also relate differences in asset holdings to differences in contemporaneous intentions about a possible return. We now provide some further results, where we condition on differences in household characteristics, and use information about contemporaneous return plans (in the case of savings), and average past return plans (in the case of asset holdings).

For both savings, home ownership and asset holdings, we estimate linear probability models (LPM) for the binary outcome variable, and OLS and Tobit models for the amount of savings.

\section{Savings}

As we discuss in section 2, it is generally ambiguous whether immigrants with temporary migration plans save more than immigrants with permanent plans. This is in line with the figures in Table 2, which show that temporary migrants are more likely to save both in the host- and the home country. Some of these differences may be due to differences in composition between the two groups. To investigate this further, we now present some conditional estimates, where we use data for two years of our panel (1992 and 1994) that provide information on the amount of savings in each location. We construct a measure for total savings, and the ratio of savings in the home vs the host country. If immigrants with temporary intentions have a higher propensity to save, we should observe that they save more than those with permanent intentions overall. If (in addition) temporary immigrants have a preference for shifting savings to the home country, then the ratio of home- to host country savings should be positively related to return plans.

Results are reported in the Table 3. In the first column, we use the total amount of savings as the dependent variable. Columns 2 and 3 distinguish between savings in the home- and host country. Column 4 reports the ratio of savings in the home country and total savings. We report LPM results in the first panel, OLS results in the second panel and Tobit results 
in the third panel. ${ }^{13}$ The point estimates on the temporary migration variable in columns 1 suggest that overall, immigrants with temporary migration plans save more than immigrants with permanent migration plans. Estimates are however not statistically significant. When splitting up savings into savings in the home- and host country, temporary migration plans are positively and significantly associated with savings for the home country only. In the last column, we report the ratio of savings in home vs host country, which is positively and significantly related to return plans. Thus, the estimates are consistent with the hypothesis that immigrants with temporary migration plans have a preference to holding their savings in the origin country rather than in the host country. They do not point at immigrants with temporary return plans saving more than immigrants with permanent plans, conditional on other observable characteristics.

\section{Property and Assets Holdings}

We now turn to property- and asset holdings of immigrants. Distinction between asset holdings in the home- and in the host country is only available for one year (1988). Assets measure the stock of assets accumulated up to 1988. As the stock of assets has been accumulated over previous years, we use the average return intention for years $1984-1988$ as a regressor. ${ }^{14}$

We show the results for property ownership in Table 4 and for overall asset holdings in Table 5, using similar specifications as above. We report the coefficient estimates for the average of return intentions over the period 1984-1988. ${ }^{15}$ We report in the first column the total amount of property ownership, while columns 2 and 3 differentiate between the property location in home

\footnotetext{
${ }^{13}$ Total amount of savings corresponds to the amount reported. See the Appendix Table 1 for full regression results with all the additional control variables for Total Savings. Those results suggest that both household income and employment of the head of the household affect savings positively. Age, years since migration, and education of the head of household do not seem to be significantly associated with household savings conditional on household income and employment of the head of the household.

${ }^{14}$ We only have information on return plans since the start of the panel in 1984.

${ }^{15}$ See the Appendix Table 2 for the full set of regression results. Household income and household size are, respectively, positively and negatively associated with asset accumulation. Furthermore, conditional on household income and household size, households with older and better educated heads hold more wealth.
} 
and host country. Column 4 reports the ratio of property holdings in the home country with respect to total property. The first panel shows the results of a simple LPM estimation on the binary outcome whether migrants have any property holdings.

The results show that on average temporary migration plans are associated with a 12.2 percentage points higher likelihood to hold property. Further, return plans are negatively associated with owning housing property in the host country, but positively associated with owning property at home. The intention to return to the home country is associated with an 8 percentage points lower likelihood to own a house in the host country, but an almost 20 percentage points higher likelihood to own a house in the home country.

In the second and third panel of the Table, we report OLS and Tobit results for the value of the property held (in 2002 Euros). These results indicate that the total value of property that immigrants with temporary migration plans hold is not significantly different from that of those with permanent plans. However, there is a stark and significant difference in the property wealth allocation between host and home countries. Those immigrants with temporary return plans hold a lower amount of property in the host country and a higher amount of property in the home country, in both OLS and Tobit specifications.

In the last column, we report again the impact of temporary migration plans on the ratio between property held in the home country, and total property holdings. As for savings, this ratio is strongly screwed towards holdings in the home country for immigrants with temporary migration intentions, in both specifications.

We show the results for asset holdings in Table 5. Again, we report the coefficient estimates for the average of return intentions over the period 1984-1988. The structure of the table is identical to the previous one. The results suggests that the total value of assets held does not differ significantly between temporary and permanent immigrants. However, the geographical location as to where assets are held is different: Households with temporary intentions hold more assets in the home country, and less in the host country, after controlling for household income and other characteristics. As the results in the last column show, the ratio of home country held assets to total assets is positively related to return plans. 


\section{Conclusions}

In this paper, we analyze savings and asset holdings of immigrants in relation to their return plans. Our analysis distinguishes between savings, housing stock and assets held in the homeand in the host country. We find evidence that return plans are associated with a different distribution of savings, property and assets between host- and home country locations.

Our results show further that there is no significant difference in total savings, property and asset holdings between immigrants with permanent and temporary migration plans, conditional on observable household background characteristics. However, immigrants with intentions to return are less likely to own property in the host country and more likely to own property in the home country, and this difference is quite substantial. Thus, our study points at immigration policies that favor permanent migrations having a different impact on the domestic housing market than policies that favor temporary policies.

Temporary migration plans are also associated with holding a higher proportion of savings and assets in the home countries. Finally, for both groups of immigrants assets held in the home country are quite substantial. Thus another important finding of our paper is that an assessment of immigrants' wealth accumulation needs to take account of wealth and assets accumulated in the home countries. This is more important, the more migrations are of a temporary character.

We should emphasize again that the relationship between the temporariness of migrations and savings- and asset accumulation behavior that we show in this paper should not be interpreted as causal. Nevertheless, our study points at possibly substantial differences in the location of savings- and asset holdings between immigrants with different intentions about the permanency of their migration. Further, we find no evidence that total savings and assets held are different between these two groups. 


\section{References}

[1] AMUEDO-DORANTES C. and S. POZO(2002), "Precautionary Savings by Young Immigrants and Young Natives", Southern Economic Journal, 69(1), pp. 48-71.

[2] BARTH E., B. BRATSBERG, O. RAAUM (2004), "Identifying earnings assimilation of immigrants under changing macroeconomic conditions", Scandinavian Journal of Economics, 106(1), pp. 1-22.

[3] BAUER T.K. and M. SINNING (2011), "The Savings Behavior of Temporary and Permanent Migrants in Germany", Journal of Population Economics, 24, pp. 421-449.

[4] BAUER T.K., D.A. COBB-ClARK, V. HILDEBRAND, M. SinNING (2011), "A Comparative Analysis of the Nativity Wealth Gap", Economic Inquiry, forthcoming.

[5] BLAU F.D. and J. W. GRAHAM (1990), "Black-White Differences in Wealth and Asset Composition", The Quarterly Journal of Economics, MIT Press, 105(2), pp. 321-39.

[6] BLITZ R.C. (1977), "A Benefit-Cost Analysis of Foreign Workers in West-Germany, 19571973", Kyklos, 30(3), pp. 479 - 502.

[7] BOHNING W. (1987), Studies in International Migration, St. Martin's Press, New York.

[8] BORJAS G.J. (1985), "Assimilation, Changes in Cohort Quality, and the Earnings of Immigrants", Journal of Labor Economics, 3 (4), pp. 463-489.

[9] BORJAS G.J. (1995), "Assimilation and Changes in Cohort Quality Revisited - What happened to Immigrant Earnings in the 1980s", Journal of Labor Economics, 13 (2), 201245.

[10] BORJAS G. J. (2002), "Homeownership in the immigrant population", Journal of Urban Economics, Elsevier, 52(3), pp. 448-476.

[11] BRATSBERG B., E. ERLING, O. RAAUM (2006), "Local Unemployment and the Relative Wages of Immigrants: Evidence from the Current Population Surveys", The Review of Economics and Statistics, 88 (2), pp. 243-263. 
[12] BUNDESAGENTUR FUER ARBEIT (2009), Arbeitslosigkeit im Zeitverlauf, http://www.pub.arbeitsamt.de/hst/services/statistik/detail/z.html.

[13] BUNDESBANK (2008), "Financial Accounts for Germany 1991 to 2007", http://www.bundesbank.de/download/statistik/finanzierungsrechnung/anlageverhalten ${ }_{1} 991_{2}$ 007.en.x

[14] CHISWICK B.R. (1978), "The Effect of Americanization on the Earnings of Foreign-born Men", The Journal of Political Economy, 86 (5), pp. 897-921.

[15] COBB-CLARK D.A. and HILDEBRAND, V. (2006), "The Wealth And Asset Holdings Of U.S.-Born And Foreign-Born Households: Evidence From Sipp Data", Review of Income and Wealth, Blackwell Publishing, 52(1), pp. 17-42.

[16] COULSON N. E. (1999), "Why Are Hispanic and Asian-American Homeownership Rates So Low? Immigration and Other Factors", Journal of Urban Economics, 45(2), pp. 209-227.

[17] DUSTMAnN C. (1993), "Earnings Adjustment of Temporary Migrants", Journal of Population Economics, 6, pp. 153-168.

[18] DUSTMANN C. (1995), "Savings Behavior of Migrant Workers - A Life Cycle Analysis", Zeitschrift fuer Wirtschafts- und Socialwissenschaften, 4, pp. 511 - 533.

[19] DUSTMANN C. (1996), "Return Migration: The European Experience", Economic Policy, 22, pp. 215-250.

[20] DUSTMANN C. (1997), "Return Migration, Uncertainty and Precautionary Savings", Journal of Development Economics, 52, pp. 295-316.

[21] DUSTMANN C., O. KIRCHKAMP (2002), "The optimal migration duration and activity choice after remigration", Journal of Development Economics, 67, 351-72.

[22] DUSTMANN C., J. MESTRES (2010), "Remittances and temporary migration", Journal of Development Economics, 92(1), pp.62-70. 
[23] FRIEDBERG R.M. (1993), "The Labor Market Assimilation of Immigrants in the United States: The Role of Age at Arrival", Brown University manuscript.

[24] GALOR O. and O. STARK (1990), "Migrants' Savings, the Probability of Return Migration and Migrants' Performance", International Economic Review, 31(2), pp. 463-67.

[25] LUBOTSKY D. (2007), "Chutes or Ladders? A Longitudinal Analysis of Immigrant Earnings", Journal of Political Economy, 115(5), 820-867.

[26] MESNARD A. (2004), "Temporary migration and capital market imperfections", Oxford Economic Papers, vol. 56, pp. 242-262.

[27] OECD (2006), International Migration Outlook: SOPEMI 2006 Edition.

[28] OSILI U. O. and A. PAULSON (2004), "Prospects for Immigrant-Native Wealth Assimilation: Evidence from Financial Market Participation", Working Paper 04-18, Federal Reserve Bank of Chicago.

[29] PAINTER G., L. YANG, Z. YU (2003), "Heterogeneity in Asian American homeownership: the impact of household endowments and immigrant status", Urban Studies, 40, pp. 505-530.

[30] SINNING M. (2007), "Wealth and Asset Holdings of Immigrants in Germany", IZA Discussion Paper No. 3089.

[31] SINNING M. (2009), "Home-Ownership and Economic Performance of Immigrants in Germany", Urban Studies, 47, pp. 387-409.

[32] WOODRUFF C. and R. ZENTENO (2007), "Migration networks and microenterprises in Mexico", Journal of Development Economics, 82(2), pp. 509-528.

[33] YANG D. (2008), "International Migration, Remittances and Household Investment: Evidence from Philippine Migrants' Exchange Rate Shocks", The Economic Journal, vol. 118, 528, pp. 591-630. 


\section{Appendix}

\section{Data Construction}

We use data from the German Socio-Economic Panel. Asset holdings are reported for the year 1988, based on a special survey module. Savings are reported for the years 1992 and 1994 . Our sample consists of immigrant households whose head was born in Turkey, Greece, Yugoslavia, Italy or Spain.

Information on return plans are provided in each wave of the panel. Individuals were asked whether they intend to remain permanently in Germany, or whether they wish to return home at some stage in the future. We construct a binary variable that defines as temporary those who plan to return in the future.

As return plans may change, and asset accumulation is related to past return intentions, we construct an average return intention variable for the last five years before assets are measured (that is, 1984-1988).

All our income variables are reported in real terms (deflated to Euros, with 2002 as the base year), and at household level. Household income corresponds to the net monthly income of the household transformed to annual level. The exact wording of the question is "If everything is taken together: how high is the total monthly income of all the household members at present? Please give the monthly net amount, the amount after the deduction of tax and national insurance contributions. Regular payments such as rent subsidy, child benefit, government grants, subsistence allowances, etc., should be included. If not known exactly, please estimate the monthly amount."

Information on household savings in the home country is available for the years 1984-1990, 1992 and 1994, and corresponds to the yearly amount saved in the home country by the household. The question asks individuals to declare the amount sent or taken to the home country for the purpose of "savings for later"; we transform this variable to the household level. Information on household savings in the host country is available for the year 1992 onwards and corresponds to the net monthly savings of the household transformed to yearly level. The question survey asked is "Do you usually have an amount of money left over each month for major purchases, 
emergencies, or savings? If yes, how much?". This implies that information on savings in both the home and the host country is available only for two years (1992 and 1994). For those years, we construct the total amount of savings as the sum of savings in both locations.

We use asset information drawn from questions in a special survey in year 1988 where immigrants where asked for their asset holdings both in the home and in the host country separately.

Asset holdings refer to the total amount of asset holdings (including cash, savings, property, etc.) but net of financial obligations, both in the home and host countries. The wording of the question is "If you could add up all the wealth of this household (including cash, goods and property you own but without furniture), what will be the approximate total value of it? Please make sure to subtract all the mortgages, loans and credits that you could have on them". Property includes the houses, apartments or any other property at market prices, both in the home and host countries. For each type of property, the wording of the question is "Are you the owner of (specific type of property)? If yes, how much do you estimate its commercial value is, that is, how much money will you get if you sold it now?" All entries correspond to the aggregated household amounts declared in the year 1988, in Euros, deflated to the base year 2002. 
Table 1 : Summary Statistics

\begin{tabular}{lrr} 
& Mean & Std. Dev. \\
\hline Age & 45.46 & 11.29 \\
Age At Arrival & 23.73 & 9.16 \\
Years Since Migration & 21.76 & 5.87 \\
Number Years Education & 9.43 & 1.92 \\
Household Income & 25186 & 12157 \\
Number Children in Household & 0.85 & 1.07 \\
Number Adults in Household & 2.66 & 1.21 \\
Number Employed Individuals in Household & 1.59 & 0.94 \\
Sex & 0.88 & 0.32 \\
Employed & 0.78 & 0.41 \\
Non Single & 0.93 & 0.25 \\
Native Partner & 0.07 & 0.26 \\
Spouse Abroad & 0.04 & 0.19 \\
Children Abroad & 0.07 & 0.26 \\
Rural Childhood & 0.39 & 0.49 \\
Temporary & 0.51 & 0.50 \\
Number of Observations & & \\
\end{tabular}

Note: Calculations based on GSOEP data, 1988, 1992, 1994. Individual information corresponds to the head of household. Household Income in 2002 Euros. 
Table 2: Savings, Home Ownership and Assets

\begin{tabular}{|c|c|c|c|c|c|c|c|c|c|c|}
\hline \multirow[b]{2}{*}{ Savings } & \multicolumn{2}{|c|}{ All Immigrants } & \multicolumn{2}{|c|}{ Temporary Immigrants } & \multicolumn{2}{|c|}{ Permanent Immigrants } & \multirow{2}{*}{$\begin{array}{c}\text { Mean Difference } \\
\text { Temporary - Permanent } \\
\text { Migrants }\end{array}$} & \multirow[b]{2}{*}{$t$} & \multicolumn{2}{|c|}{ Natives } \\
\hline & Mean & $N$ & Mean & $N$ & Mean & $N$ & & & Mean & $N$ \\
\hline \multicolumn{11}{|l|}{ In Host Country } \\
\hline Proportion that saves & $48.3 \%$ & 1871 & $50.4 \%$ & 782 & $46.7 \%$ & 1089 & $3.6 \%$ & 1.55 & & \\
\hline $\begin{array}{l}\text { Average Amount } \\
\text { (Std.Dev.) }\end{array}$ & $\begin{array}{l}2046 \\
(3655)\end{array}$ & 1871 & $\begin{array}{l}2218 \\
(3585)\end{array}$ & 782 & $\begin{array}{c}1922 \\
(3700)\end{array}$ & 1089 & 297 & 1.74 & & \\
\hline Average Value as Percentage $\mathrm{HH}$ Income & $7.4 \%$ & 1809 & $8.0 \%$ & 754 & $7.0 \%$ & 1055 & $1.0 \%$ & 1.89 & & \\
\hline \multicolumn{11}{|l|}{ In Home Country } \\
\hline Proportion & $4.8 \%$ & 1902 & $7.3 \%$ & 797 & $3.0 \%$ & 1105 & $4.3 \%$ ** & 4.35 & & \\
\hline $\begin{array}{l}\text { Average Amount } \\
\text { (Std.Dev.) }\end{array}$ & $\begin{array}{c}155 \\
(1207)\end{array}$ & 1902 & $\begin{array}{c}230 \\
(1127)\end{array}$ & 797 & $\begin{array}{c}101 \\
(1259)\end{array}$ & 1105 & $129 *$ & 2.31 & & \\
\hline Average Value as Percentage $\mathrm{HH}$ Income & $0.7 \%$ & 1838 & $0.9 \%$ & 769 & $0.5 \%$ & 1069 & $0.3 \%$ & 1.26 & & \\
\hline \multicolumn{11}{|l|}{ Total Sum Home and Host Country } \\
\hline Proportion & $49.8 \%$ & 1871 & $52.8 \%$ & 782 & $47.6 \%$ & 1089 & $5.2 \%$ * & 2.24 & $65.4 \%$ & 6901 \\
\hline $\begin{array}{l}\text { Average Amount } \\
\text { (Std.Dev.) }\end{array}$ & $\begin{array}{l}2199 \\
(3921)\end{array}$ & 1871 & $\begin{array}{c}2448 \\
(3835)\end{array}$ & 782 & $\begin{array}{l}2021 \\
(3974)\end{array}$ & 1089 & 427 * & 2.32 & $\begin{array}{l}2888 \\
(5101)\end{array}$ & 6901 \\
\hline Average Value as Percentage $\mathrm{HH}$ Income & $8.1 \%$ & 1809 & $8.8 \%$ & 754 & $7.5 \%$ & 1055 & $1.3 \%$ * & 2.17 & $9.9 \%$ & 6688 \\
\hline \multicolumn{11}{|l|}{ Home Ownership } \\
\hline \multicolumn{11}{|l|}{ In Host Country } \\
\hline Proportion that Holds Property & $8.4 \%$ & 860 & $5.5 \%$ & 577 & $14.1 \%$ & 283 & $-8.6 \%$ ** & -4.31 & & \\
\hline $\begin{array}{l}\text { Average Value } \\
\text { (Std.Dev.) }\end{array}$ & $\begin{array}{c}13814 \\
(55896)\end{array}$ & 857 & $\begin{array}{c}7324 \\
(38995)\end{array}$ & 575 & $\begin{array}{c}27049 \\
(78417)\end{array}$ & 282 & $-19726 * \star$ & -4.91 & & \\
\hline \multicolumn{11}{|l|}{ In Home Country } \\
\hline Proportion that Holds Property & $44.2 \%$ & 859 & $50.5 \%$ & 576 & $31.4 \%$ & 283 & $19.1 \%$ ** & 5.37 & & \\
\hline $\begin{array}{l}\text { Average Value } \\
\text { (Std.Dev.) }\end{array}$ & $\begin{array}{c}30043 \\
(59823)\end{array}$ & 835 & $\begin{array}{c}36764 \\
(66816)\end{array}$ & 560 & $\begin{array}{c}16356 \\
(38792)\end{array}$ & 275 & 20408 ** & 4.69 & & \\
\hline \multicolumn{11}{|l|}{ Total Sum Home and Host Country } \\
\hline Proportion that Holds Property & $49.9 \%$ & 859 & $53.8 \%$ & 576 & $42.0 \%$ & 283 & $11.8 \%$ ** & 3.26 & $43.6 \%$ & 3329 \\
\hline Average Value & 44381 & 832 & 44443 & 558 & 44255 & 283 & 188 & 0.03 & 60973 & 3194 \\
\hline (Std.Dev.) & $(81167)$ & & (78167) & & (87108) & & & & (111939) & \\
\hline \multicolumn{11}{|l|}{ Asset Holdings } \\
\hline \multicolumn{11}{|l|}{ In Host Country } \\
\hline Proportion that Holds Assets & $73.4 \%$ & 629 & $74.0 \%$ & 400 & $72.5 \%$ & 229 & $1.5 \%$ & 0.041 & & \\
\hline $\begin{array}{l}\text { Average Value } \\
\text { (Std.Dev.) }\end{array}$ & $\begin{array}{c}31649 \\
(96379)\end{array}$ & 629 & $\begin{array}{c}20805 \\
(126877)\end{array}$ & 400 & $\begin{array}{c}50591 \\
(128105)\end{array}$ & 229 & $-29786 * *$ & -3.76 & & \\
\hline \multicolumn{11}{|l|}{ In Home Country } \\
\hline Proportion that Holds Assets & $71.6 \%$ & 595 & $75.7 \%$ & 423 & $61.6 \%$ & 172 & $14.0 \%$ ** & 3.46 & & \\
\hline $\begin{array}{l}\text { Average Value } \\
\text { (Std.Dev.) }\end{array}$ & $\begin{array}{c}48723 \\
(75382)\end{array}$ & 595 & $\begin{array}{c}54130 \\
(81975)\end{array}$ & 423 & $\begin{array}{c}35424 \\
(53899)\end{array}$ & 172 & 18706 ** & 2.76 & & \\
\hline \multicolumn{11}{|l|}{ Total Sum Home and Host Country } \\
\hline Proportion that Holds Assets & $83.7 \%$ & 486 & $84.3 \%$ & 331 & $82.6 \%$ & 155 & $1.7 \%$ & 0.48 & $79.8 \%$ & 2959 \\
\hline $\begin{array}{l}\text { Average Value } \\
\text { (Std.Dev.) }\end{array}$ & $\begin{array}{c}66777 \\
(103651)\end{array}$ & 486 & $\begin{array}{c}65949 \\
(96608)\end{array}$ & 331 & $\begin{array}{c}68544 \\
(117606)\end{array}$ & 155 & -2595 & 0.25 & $\begin{array}{c}104966 \\
(162877)\end{array}$ & 2959 \\
\hline
\end{tabular}

Note: Calculations based on GSOEP data on household level. Average amount (in 2002 Euros) not conditional on reporting any positive amount. Property Ownership includes house, apartment or any other property. Asset holdings refer to the total amount of asset holdings net of financial obligations, including cash, savings, property, etc. Savings in the host country corresponds to the net monthly savings of the household transformed to annual amount. Savings in the home country corresponds to the yearly amount remitted to the home country and that is saved. Both Property Ownership and Asset holdings refer to the year 1988. Savings Flows refer to years 1992 and 1994 . We use all observations for which respective information is available.

* significant mean difference at $5 \% ;{ }^{* *}$ significant mean difference at $1 \%$ 
Table 3: Savings - Home and Host Country

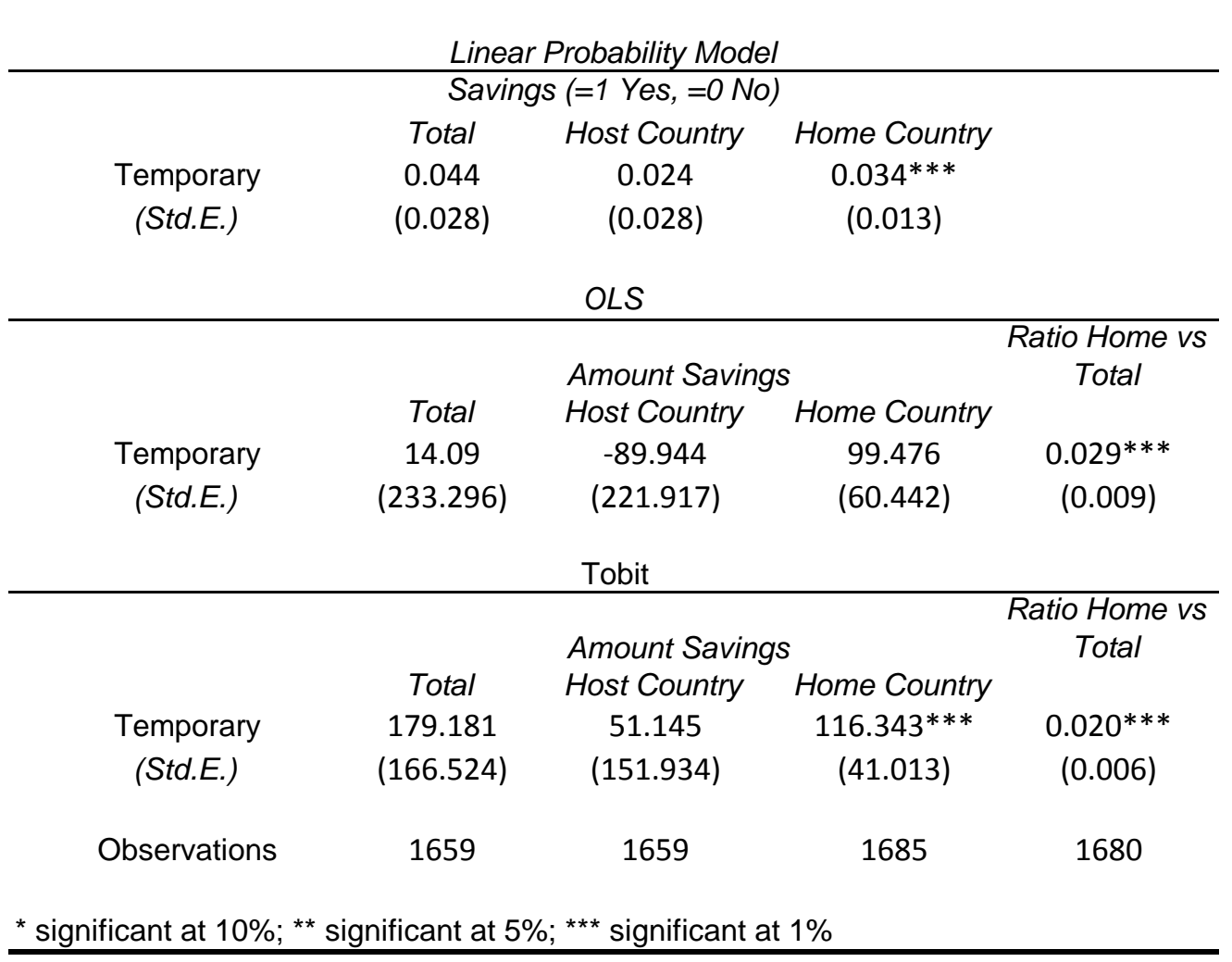

Note: GSOEP data (1992 and 1994). Household level. All specifications include time and country dummies and condition on age, years since migration (and its square), education, gender, marital status and employment status of the head of household as well as household income and number of adults and children in the host country household. Standard errors are clustered by household. Tobit results show unconditional marginal effects. Reported coefficents correspond to the coefficient on the contemporary temporary intention variable. 
Table 4: Property Ownership - Home and Host Country

\begin{tabular}{|c|c|c|c|c|}
\hline \multicolumn{5}{|c|}{ Linear Probability Model } \\
\hline \multicolumn{5}{|c|}{ Property Ownership $(=1$ Yes, =0 No) } \\
\hline \multirow{4}{*}{$\begin{array}{c}\text { Temporary } \\
\text { (Std.E.) }\end{array}$} & Total & Host Country & Home Country & \\
\hline & $0.122^{*}$ & $-0.079^{\star \star}$ & $0.190^{* *}$ & \\
\hline & $(0.055)$ & $(0.03)$ & $(0.054)$ & \\
\hline & \multicolumn{4}{|c|}{ OLS } \\
\hline \multicolumn{5}{|c|}{ Amount Property } \\
\hline \multirow{5}{*}{$\begin{array}{c}\text { Temporary } \\
\text { (Std.E.) }\end{array}$} & & & & Ratio Home vs \\
\hline & Total & Host Country & Home Country & Total \\
\hline & 7456.369 & $-22919.058 * *$ & $30939.940 * *$ & $0.214^{* *}$ \\
\hline & $(8832.433)$ & $(5565.475)$ & $(6773.723)$ & $(0.054)$ \\
\hline & \multirow{2}{*}{\multicolumn{4}{|c|}{ Tobit }} \\
\hline \multicolumn{4}{|c|}{ Amount Property } & \\
\hline \multirow{4}{*}{$\begin{array}{c}\text { Temporary } \\
\text { (Std.E.) }\end{array}$} & & & & Ratio Home vs \\
\hline & Total & Host Country & Home Country & Total \\
\hline & 11678.86 & $-4573.934 * *$ & $28297.509 * *$ & $0.243^{* *}$ \\
\hline & (7608.978) & (1520.867) & (5849.031) & $(0.061)$ \\
\hline Observations & 739 & 738 & 719 & 739 \\
\hline ignificant at $5 \%$ & cant at $1 \%$ & & & \\
\hline
\end{tabular}

Note: GSOEP data (1988). Household level. All specifications include time and country dummies and condition on age, years since migration (and its square), education, marital status, household income, employment status and number of adults and children in the host country household. Property ownership includes the purchase of house, apartment or any other property, in the host and in the home country. Tobit results show unconditional marginal effects. Reported coefficents correspond to the average intention to return up to 1988 (1984-1988). 
Table 5: Asset Holdings - Home and Host Country

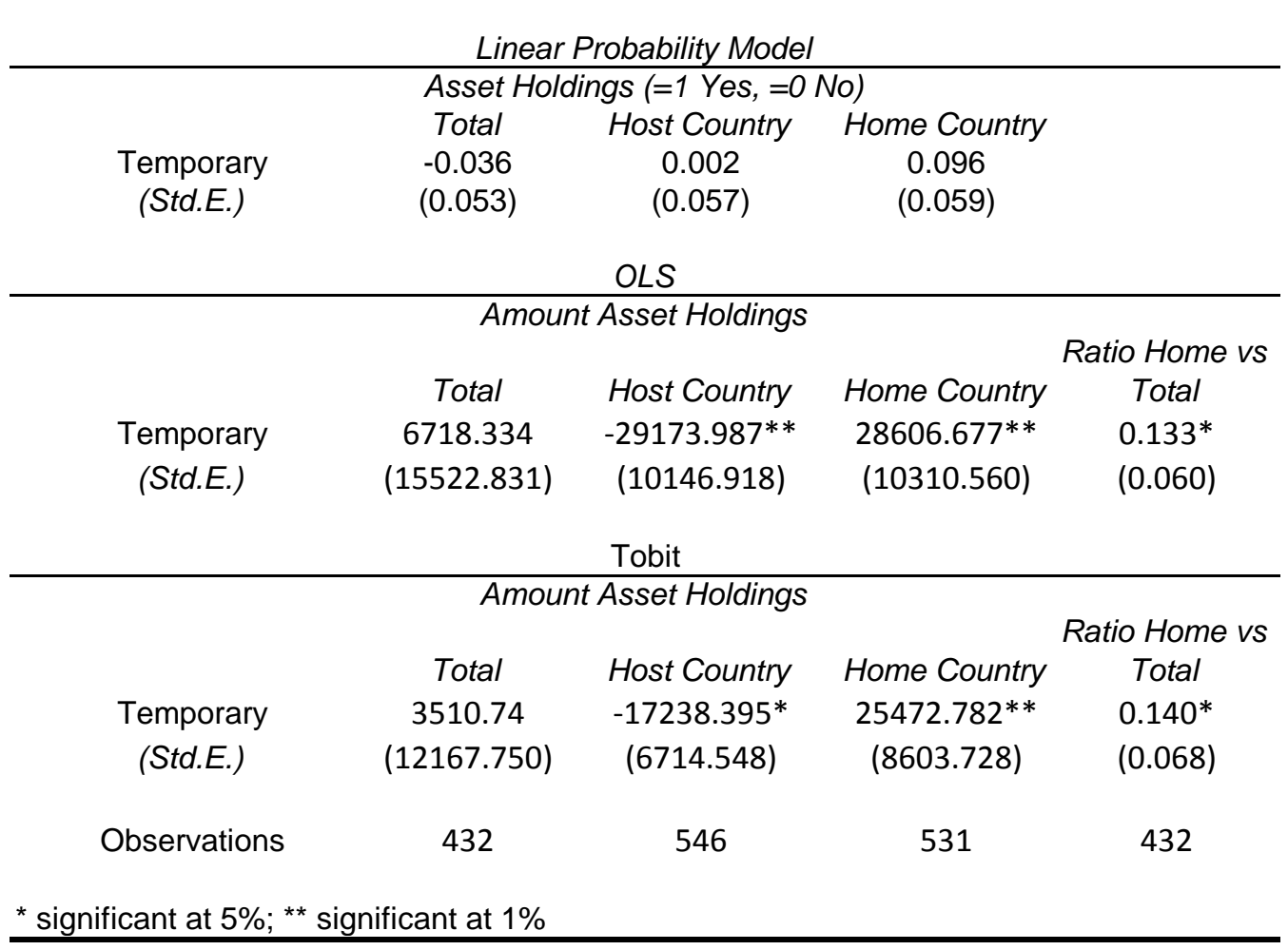

Note: GSOEP data (1988). Household level. All specifications include time and country dummies and condition on age, years since migration (and its square), education, marital status, household income, employment status and number of adults and children in the host country household. Asset holdings refer to the total amount of asset holdings net of financial obligations, including cash, savings, property, etc., in the host and in the home country. Tobit results show unconditional marginal effects. Reported coefficents correspond to the average intention to return up to 1988 (1984-1988). 


\begin{tabular}{|c|c|c|c|}
\hline & \multicolumn{3}{|c|}{ Total Savings } \\
\hline & \multirow{2}{*}{$\begin{array}{c}(=1 \text { Yes, }=0 \mathrm{No}) \\
L P M\end{array}$} & \multicolumn{2}{|c|}{ Amount } \\
\hline & & $O L S$ & TOBIT \\
\hline Age/10 & -0.001 & 20.828 & 15.043 \\
\hline (Std.E.) & $(0.002)$ & $(20.377)$ & $(10.888)$ \\
\hline Years Since Migration/10 & 0.063 & -72.385 & -44.678 \\
\hline (Std.E.) & $(0.100)$ & (954.475) & (579.814) \\
\hline YSM-Squared/100 & -0.019 & -131.676 & -92.917 \\
\hline (Std.E.) & $(0.024)$ & (197.844) & (133.413) \\
\hline Log HH Income & $0.286 * * *$ & $2691.025^{* * *}$ & $4072.837^{* * *}$ \\
\hline (Std.E.) & $(0.089)$ & $(935.280)$ & $(255.809)$ \\
\hline Number Adults HH Host & $-0.047 * *$ & -280.394 & $-469.503 * * *$ \\
\hline (Std.E.) & $(0.021)$ & $(219.850)$ & $(107.843)$ \\
\hline Number Children HH Host & $-0.073 * * *$ & $-352.268 * * *$ & $-433.709 * * *$ \\
\hline (Std.E.) & $(0.014)$ & $(118.826)$ & (79.531) \\
\hline Employment Head HH & $0.152 * * *$ & 62.768 & $642.021 * * *$ \\
\hline (Std.E.) & $(0.038)$ & (292.701) & $(233.220)$ \\
\hline Number Employed $\mathrm{HH}$ & 0.002 & 236.447 & -212.843 \\
\hline (Std.E.) & $(0.029)$ & (282.581) & (129.628) \\
\hline Number Years Education & 0.003 & -57.785 & -57.937 \\
\hline (Std.E.) & $(0.007)$ & $(51.418)$ & (38.930) \\
\hline Male Head HH & 0.019 & 167.13 & 97.344 \\
\hline (Std.E.) & $(0.040)$ & (469.024) & $(234.473)$ \\
\hline Non Single & $-0.107 * *$ & $-829.918^{* *}$ & $-889.294^{* * *}$ \\
\hline (Std.E.) & $(0.049)$ & (357.352) & $(288.561)$ \\
\hline Native Partner & 0.072 & 397.2 & 369.201 \\
\hline (Std.E.) & $(0.053)$ & $(403.186)$ & (269.934) \\
\hline Spouse Abroad & 0.084 & 947.252 & $1127.213^{* * *}$ \\
\hline (Std.E.) & $(0.083)$ & (623.977) & $(432.572)$ \\
\hline Children Abroad & -0.067 & 529.332 & 213.764 \\
\hline (Std.E.) & $(0.064)$ & (665.530) & (343.230) \\
\hline Rural Childhood & $0.047^{*}$ & 238.197 & $354.596 * *$ \\
\hline (Std.E.) & (0.028) & $(230.128)$ & $(154.448)$ \\
\hline Temporary & 0.044 & 14.09 & 179.181 \\
\hline (Std.E.) & $(0.028)$ & (233.296) & $(166.524)$ \\
\hline Number of Observations & 1659 & 1659 & 1659 \\
\hline R-squared & 0.142 & 0.151 & 0.024 \\
\hline
\end{tabular}

Note: GSOEP data (1992 and 1994). Household level. All specifications include time and country dummies. Standard errors are clustered by household. 
Appendix Table 2: Total Property and Asset Holdings

\begin{tabular}{|c|c|c|c|c|c|c|}
\hline & \multicolumn{3}{|c|}{ Total Property } & \multicolumn{3}{|c|}{ Total Asset Holdings } \\
\hline & \multirow{2}{*}{$\begin{array}{c}(=1 \text { Yes, }=0 \mathrm{No}) \\
L P M\end{array}$} & \multicolumn{2}{|c|}{ Amount } & \multirow{2}{*}{$\begin{array}{c}(=1 \text { Yes, }=0 \text { No }) \\
L P M\end{array}$} & \multicolumn{2}{|c|}{ Amount } \\
\hline & & OLS & TOBIT & & OLS & TOBIT \\
\hline Age/10 & $0.065^{*}$ & 6992.39 & $8167.744 *$ & $0.066^{\star *}$ & $20423.945^{* *}$ & $19354.011^{* *}$ \\
\hline (Std.E.) & $(0.026)$ & $(4123.640)$ & (3567.110) & $(0.025)$ & (7165.884) & $(5616.612)$ \\
\hline Years Since Migration/10 & $0.439^{*}$ & 13363.174 & 42990.847 & 0.084 & -40474.467 & -21355 \\
\hline (Std.E.) & $(0.223)$ & (35502.003) & (31944.141) & $(0.228)$ & $(66282.065)$ & $(52034.042)$ \\
\hline YSM-Squared/100 & -0.104 & -1594.633 & -9021.404 & -0.035 & 12131.839 & 5675.163 \\
\hline (Std.E.) & $(0.055)$ & (8818.495) & (7884.666) & $(0.057)$ & $(16414.831)$ & $(12929.400)$ \\
\hline Log HH Income & $0.344^{* *}$ & $57212.046 * *$ & $58354.315 * *$ & $0.342^{* *}$ & $108771.151 * *$ & $100564.981 * *$ \\
\hline (Std.E.) & $(0.061)$ & (9691.445) & $(8676.121)$ & $(0.062)$ & $(18119.010)$ & $(14485.252)$ \\
\hline Number Adults HH Host & -0.028 & $-6545.521 *$ & $-6026.319 * *$ & -0.03 & -5194.61 & -5626.295 \\
\hline (Std.E.) & $(0.016)$ & (2666.964) & $(2269.345)$ & $(0.016)$ & (4546.187) & (3557.839) \\
\hline Number Children HH Host & -0.027 & -932.913 & -1940.823 & -0.007 & -79.446 & -266.035 \\
\hline (Std.E.) & $(0.018)$ & (2948.062) & $(2504.003)$ & $(0.017)$ & (4933.143) & (3833.999) \\
\hline Employment Head $\mathrm{HH}$ & 0.021 & -1801.02 & 1709.037 & 0.028 & 14874.005 & 13933.759 \\
\hline (Std.E.) & $(0.058)$ & (9181.844) & (7806.949) & $(0.056)$ & $(16136.560)$ & $(12670.834)$ \\
\hline Number Employed HH & -0.013 & -2358.308 & -3104.786 & -0.032 & $-15353.334^{*}$ & $-13211.824 *$ \\
\hline (Std.E.) & $(0.029)$ & (4635.975) & (3859.390) & $(0.027)$ & (7779.869) & $(6112.197)$ \\
\hline Number Years Education & -0.014 & 2321.072 & 366.429 & -0.012 & $7329.063^{* *}$ & $4813.823^{*}$ \\
\hline (Std.E.) & $(0.010)$ & (1568.693) & (1330.714) & $(0.009)$ & (2737.697) & (2151.789) \\
\hline Male Head $\mathrm{HH}$ & 0.172 & 18773.464 & 25832.981 & -0.007 & 29624.491 & 19496.307 \\
\hline (Std.E.) & $(0.094)$ & $(15077.112)$ & (15119.807) & $(0.127)$ & $(36803.571)$ & $(28689.586)$ \\
\hline Native Partner & 0.015 & 25354.86 & 17984.492 & -0.025 & $66389.392 *$ & $51424.168 *$ \\
\hline (Std.E.) & $(0.081)$ & $(13105.281)$ & (11312.488) & $(0.101)$ & (29301.068) & $(22861.355)$ \\
\hline Spouse Abroad & -0.068 & -9697.935 & -8631.509 & -0.084 & -19941.21 & -19590.228 \\
\hline (Std.E.) & $(0.087)$ & (13894.105) & $(11827.956)$ & $(0.081)$ & $(23635.383)$ & $(18863.518)$ \\
\hline Children Abroad & $0.128^{*}$ & 13884.182 & $15725.938 *$ & 0.006 & 25068.459 & 19478.381 \\
\hline (Std.E.) & $(0.057)$ & (9335.730) & (7599.675) & $(0.052)$ & (15167.549) & (11837.909) \\
\hline Rural Childhood & -0.01 & 5437.249 & 3562.898 & -0.006 & 6965.387 & 4994.18 \\
\hline (Std.E.) & $(0.037)$ & (5901.585) & (4932.460) & $(0.034)$ & (9993.592) & (7791.598) \\
\hline Temporary & $0.122^{*}$ & 7456.369 & 11678.86 & -0.036 & 6718.334 & 3510.74 \\
\hline (Std.E.) & $(0.055)$ & (8832.433) & (7608.978) & $(0.053)$ & $(15522.831)$ & $(12167.750)$ \\
\hline Number of Observations & 738 & 718 & 718 & 432 & 432 & 432 \\
\hline R-squared & 0.138 & 0.117 & 0.011 & 0.131 & 0.18 & 0.01 \\
\hline
\end{tabular}

Note: GSOEP data (1992 and 1994). Household level. All specifications include time and country dummies. Standard errors are clustered by household. 